\title{
Science Motivation of University Students: Achievement Goals as a Predictor
}

\author{
Serhat Arslan", Mehmet Akcaalan,, ${ }^{2}$, Cengiz Yurdakul ${ }^{1}$ \\ ${ }^{1}$ Faculty of Education, Sakarya University, Turkey \\ ${ }^{2}$ Institute of Education Sciences, Eskişehir Osmangazi University, Turkey
}

Copyright $(2017$ by authors, all rights reserved. Authors agree that this article remains permanently open access under the terms of the Creative Commons Attribution License 4.0 International License

\begin{abstract}
The objective of this investigation is to make a study of the relationship between achievement goals and science motivation. Research data were collected from 295 university students. Achievement goals and science motivation scales were utilized as measure tools. The link between achievement goals orientation and science motivation was investigated by statistical package for social sciences. Correlation analysis demonstrated that sub dimensions of achievement goals; related positively to science motivation. Besides, the connection between achievement goals and science motivation still requires further research because of some limitations. Thus, in addition to intervention strategies, further investigation should include more factors for achievement goals and investigate its effect on adolescents' science motivation. Findings were discussed with regard to the relevant literature.
\end{abstract}

Keywords Achievement Goals, Science Motivation, Stepwise Regression Analysis

\section{Introduction}

The theory of achievement goals explains why various levels of success in individuals with the similar competence and level of intelligence develops out of the different features of motivation and goals that they set so as to be successful [17]. This theory was investigated to demonstrate how the achievement level of students may be different with the same intelligence and ability capacity [14]. The achievement goal orientations have been comprehensively examined by some educational scientists in the area of educational psychology [1] and they described it a combinatorial design of beliefs, characteristics, and influences that produce purposes of behavior [2]. According to the achievement goal theory, students differ from each other with regard to their achievement behaviors. These different aspects of students are related to distinctive emotional, motivational, cognitive, and behavioral outcomes [33]. Individuals are influenced by the beliefs about themselves which have an effect on how they perform a task or what they really do. If a person considers that some characteristics such as intelligence can be developed, they gear up for to improve it and this stimulates them to do much better at school [15].

Achievement goals are "proficiency-relevant goals that a person makes an effort in success environment" [16]. They were conceptualized by Elliot and McGregor [15] in a 2x2 framework. A $2 \times 2$ framework of achievement goal orientations has been propounded that involves mastery (e.g., motivated to comprehend the material and improve their skills) and performance (e.g., related to comparing themselves with other students) goal orientations. A mastery-approach (M-ap) goal orientation (i.e., a desire to maximize learning and ability development), and a mastery-avoidance (M-av) goal orientation, (i.e., a concern of losing some skills or the inability to master all the materials) are the two models that can be gained by students. Achievement goals were described by Elliot and McGregor [15] as a 2x2 framework. (1) M-ap goals - the target searches for learning and knows well the assignment. (2) $\mathrm{M}$-av goals - keeping off the assignment due to sense of imperfection and inadequacy of succession the assignment. (3) Performance approach (P-ap) - concentrating upon doing better than other people. (4) Performance avoidance (P-av) - keeping off fulfilling insufficient comparing with others. The practicability of $2 \times 2$ achievement goal orientations pattern was investigated and experimental reinforcement was explored for the differentiation of the $2 \times 2$ goal orientations in the factor analyses [15]. Researchers have lately differentiated in personal mastery goals. When the literature is viewed, there are many investigations related to the current researches. According to Midgley and Urdan [31] investigated the relationships individual achievement targets, apprehensions of the schoolroom aim pattern and states of the utilization of personal handicapping ways among the students. As a conclusion of their research, students who were lower in 
task aims handicapped and P-av goals more than the students who were lower in P-av goals and higher in task aims. There was a little effect of P-ap goals level from the point of the link between handicapping and task aims. A research performed by Kaplan and Maehr [22], about the achievement goals, is possible to act in enabling the psychological well-being of students. Positive psychological well-being was in relationship with task aims and apprehension of the school as stressing task aims. Moreover, adverse psychological well-being was related to ego aims and apprehension the school as stressing ego aims. According to Pajares and others [36], task aims were in negative relationship with science apprehension. $\mathrm{P}$-av goals were in positive relationship with science apprehension. Researchers detected a significant relationship between task aims and P-ap goals in the science field.

\subsection{Science Motivation}

Improving all science literacy of the students is the aim of science instruction, so it is indispensable to encourage students to comprehend important science notions, to recognize the significance of science and improvement in technology, to comprehend the disposition of science, and to voluntarily maintain their education of science at school [NRC, 1996]. Therefore, student cognition and the affective components of cognition should be addressed together by researches in science teaching and learning. Inside of the effective factors, motivation is crucial since motivation of students plays a crucial role in their notional conversion processes [23,24,34,35]. In that vein, students' motivation plays another fundamental role in critical thinking and learning strategies of students $[19,21,42]$. On the other hand, according to Napier and Riley [28], motivation has significant influence on science learning achievement. Together with environmental and social contribution, both talent and ambition are necessary in learning $[26,44]$. Current views of learning refer to the significance of the idea that both cognition, motivation and will of students are fundamental elements on account of prosperous achievement and learning [20,40]. Students' motivation becomes visible in their efficient participation in the process of learning, eager approach of difficult learning tasks, dense diligence sacrifices along the utilization of strategies in active learning, permanency in accomplishing problem solving and learning considering difficulties $[7,32,35,43]$. Considerably motivated individuals who are more worried about own process of learning and results, demonstrate larger progress, more advanced levels of mastery, and attempt higher reassurance and positive effect than inadequate motivated students [40,43]. Literature review shows that many examinations about science motivation were fulfilled. Accordingly, Glynn and others (2011) investigated the students' motivation to study science. Findings suggest that the motivation elements - self-determination, self-efficacy, motivation of intrinsic, motivation of career and motivation of grade act a significant role in individuals' science achievement. Meece and Jones [29] researched gender differences in mid-school individuals' confidence, motivation goals, and ways of learning in science lessons. Their study showed a few gender differences. Male students reported more confidence in their science capabilities compared to female students. Stake [41] examined the dimension of social stimulations that conducts the relationship of position and motivation of science and self-reliance. The results demonstrated that stimulation from parents, instructors from school, and friends were each unconnected variables of science motivation. Another study of Bryan and others (2011) examined the motivation of 1416 year old learners to learn science. According to the findings, the intrinsic motivation, self-efficacy, self-determination, and achievement of the students were in relationship. The investigation claims that teachers of science had better use social patterns and tasks of collaborative-learning to facilitate motivation, achievement and interest of students' in science lessons.

\subsection{The Present Study}

Researches in the area of motivation were performed with achievement goals theory as a fundamental direction in field of education [25,28,40] and, to our knowledge, any research has not been examined on achievement goals in science motivation. Therefore, the present examination's goal is to conduct the connections between achievement goals and science motivation. In the current investigation the science motivation has been taken into consideration as a result and achievement goals as the predictor. That there is a positive relationship between achievement goals and science motivation was hypothesized by the researchers $[3,8,10,11,12,14,30,38]$.

\section{Method}

\subsection{Participants}

The investigation's participators were 295 students from university, it was consisted of 170 females (57\%) and 125 males (43\%) University of Sakarya, Turkey. Ages of the students were between 18 and 36 and the participants' mean age was $20.2(\mathrm{sd}=1.9)$ years and GPA scores ranged from 1.40 to 3.87 .

\subsection{Instruments}

Achievement goals questionnaire: Achievement Goals Questionnaire consists of a 12-item paper-and-pencil scale which was adapted to Turkish by Arslan and Akın [5]. There are four subscales in the scale. The Turkish version of the Achievement Goals Questionnaire's confirmatory factor analysis was calculated. According to the applied analysis, the items loaded on four factors [5]. Confirmatory factor analysis's results demonstrated that the four-dimensional model was well fit. 
Science Motivation Scale: Science Motivation Scale is a 21 item paper-and-pencil scale. It was adapted to Turkish by Arslan, Yılmaz, Akcaalan, Yilan and Cavdar[6]. This scale has six sub-scales. For confirmatory factor analysis of the Turkish version of the Science Motivation Scale was calculated and analysis showed that the items loaded on six factors [6]. Results of confirmatory factor analysis showed that the six-dimensional model was well fit.

\subsection{Procedure}

Participants were demanded to give knowledge about the term at school and were informed to spare some time and read each item carefully. The questionnaires were applied to the individuals in group sets in the schoolrooms. The counterbalance was administrated for the measures. The participants were acquainted with the aims of the investigation prior to application of questionnaires

\subsection{Procedure and Data Analysis}

Participants were selected by the convenience sampling method. The convenience sampling was utilized in order to select the participators due to the participants' accessibility and closeness to the researcher [9]. In this research, so as to determine the connection between individuals' science motivation and achievement goals, correlation and regression analysis were performed.

\section{Findings}

\subsection{Descriptive Data and Inter-correlations}

In Table 1, preliminary correlation analysis shows that M-ap ( $\mathrm{r}=.40), \mathrm{M}$-av $(\mathrm{r}=.44), \mathrm{P}-\mathrm{ap}(\mathrm{r}=.52), \mathrm{P}-\mathrm{av}(\mathrm{r}=.47)$ are related positively associated with science motivation. In Table 2, multiple regression analysis is demonstrated that the independent variables are dimensions of between achievement goals and the dependent variable is science motivation.

Table 1. Descriptive statistics and inter-correlations of the variables

\begin{tabular}{cccccc}
\hline Variables & M-ap & M-av & P-ap & P-av & Science motivation \\
\hline M-ap & - & & & \\
M-av & $.59^{* *}$ & - & & \\
P-ap & $.62^{* *}$ & $.59^{* *}$ & - & & \\
P-av & $.56^{* *}$ & $.57^{* *}$ & $.73^{* *}$ &. & $.47^{* *}$ \\
Science motivation & $.40^{* *}$ & $.44^{* *}$ & $.52^{* *}$ & - \\
\hline
\end{tabular}
$* * p<.01$

Table 2. Summary of Stepwise Multiple Regression Analysis for Variable Predicting Science Motivation

\begin{tabular}{|c|c|c|c|c|c|c|c|c|c|}
\hline Variables & $B$ & $S E_{B}$ & $\beta$ & $T$ & $p$ & $R$ & $R^{2}$ & $F$ & $p$ \\
\hline \multicolumn{10}{|l|}{ Step 1} \\
\hline M-ap & 3.2 & .44 & .39 & 7.37 & .00 & .39 & .15 & 54.3 & .00 \\
\hline \multicolumn{10}{|l|}{ Step 2} \\
\hline M-ap & 1.7 & .53 & .21 & 3.32 & .00 & \multirow{2}{*}{.47} & \multirow{2}{*}{.22} & \multirow{2}{*}{24.0} & \multirow{2}{*}{.00} \\
\hline M-av & 2.2 & .45 & .31 & 4.9 & .00 & & & & \\
\hline \multicolumn{10}{|l|}{ Step 3} \\
\hline M-ap & .44 & .55 & .05 & .80 & .42 & \multirow{3}{*}{.54} & \multirow{3}{*}{.30} & \multirow{3}{*}{31.5} & \multirow{3}{*}{.00} \\
\hline M-av & 1.3 & .45 & .18 & 2.85 & .005 & & & & \\
\hline P-ap & 2.8 & .49 & .37 & 5.62 & .00 & & & & \\
\hline \multicolumn{10}{|l|}{ Step 4} \\
\hline M-ap & .32 & .55 & .03 & .57 & .56 & \multirow{4}{*}{.55} & \multirow{4}{*}{.30} & \multirow{4}{*}{3.26} & \multirow{4}{*}{.07} \\
\hline M-av & 1.1 & .46 & .16 & 2.4 & .01 & & & & \\
\hline P-ap & 2.2 & .58 & .30 & 3.87 & .00 & & & & \\
\hline P-av & .94 & .52 & .13 & 1.80 & .07 & & & & \\
\hline
\end{tabular}

${ }^{*} p<.01$ (Mastery-approach (M-ap), mastery-avoidance (M-av), Performance approach (P-ap), Performance avoidance (P-av) 
$\mathrm{M}$-ap is the first factor from study entering the equation first, accounting for $15 \%$ of the variance in predicting science motivation. M-av is the second step accounting for an additional $7 \%$ variance. $\mathrm{P}$-ap is the third step accounting for an additional $7 \%$ variance. $\mathrm{P}$-av is the fourth step accounting for an additional $1 \%$ variance. The last regression models M-ap, M-av, P-ap, and $\mathrm{P}-\mathrm{av}$ on as predictors of science motivation accounts for $30 \%$ of the variance in science motivation. The standardized beta coefficients indicates the relative influence of the variables in last model with $\mathrm{M}$-ap, M-av, P-ap all significantly influencing science motivation but $\mathrm{P}$-av does not predict significantly, and M-ap was strongest predictor of science motivation.

\section{Discussion and Conclusion}

The present research' primary goal was to analyse the relationship between science motivation and achievement goals. Whether achievement goals would predict students' science motivation or not was another important aim of the study. The findings unambiguously proved the hypotheses of the examination as correct. Preliminary correlation analyses indicated that M-ap, M-av, P-ap, P-av were positively associated to science motivation. Stepwise regression analysis findings demonstrated that M-ap, M-av, P-ap, P-av significantly predicted students' science motivation level. The findings of correlation and regression analyses confirmed the hypothesis and the significance of achievement goals to gain a clear understanding of science motivation. The results of the study confirmed that the science motivation's significant predictor of was related to achievement goals. In the achievement goal theory, the motivation of common interest was based on by the singular antecedents and consequences of students' goal accepting $[27,30,19]$. Researchers in the field of motivation found that higher grades were in relationship with P-ap goals [11]) and were not in relationship with the use of basic ways of learning [4,34]; and hence they should not be taken into consideration as non-adaptive for student learning. Dowson and McInerney [12] emphasized that work-avoidance was an essential side of school motivation. Especially this orientation was related to a a large quantity of diligence lessening strategies. In his study, Was [39] demonstrated that perceptions about motivation might be important for strategy of students achievement tasks in school achievement. Importance of individuals' different tendencies which effect their motivational perception was proved by some other researchers. For example, in another study of Dweck and colleagues [14] proposed that motivational model created a focus on varied aims, strategies of cognitive, influences and behavior. Besides the similar results of Tapola and Niemivirta [37], they proved that learning environment of students' perceptions and preferences varied in term of differences motivational tendencies. According to Tuan, Chin, Shieh [38], it was asserted that the permanence of motivation about the individuals' achievement indicated that motivation of students was markedly related to science achievement scores gained previously and currently. In another study, Bryan, Glynn, Kittleson [8] indicated the motivation to learn science might make it possible for students to comprehend information in science, describe fundamental questions of science, make evidence-based inferences and reach a verdict with regard how human activity influences the natural world. Additionally, the more dominant scales of students' motivation were, the more active roles they took in terms of science learning [30]. Within this context, Andrei, Izabela and Valentina [3] indicated that a higher motivation or an intentional learning improved its reproductive performance only if it was associated with a more laborious processing of the material learned. As a result, the present findings strengthen our conception of the link between science motivation and achievement goals. In contrast with expressed limitations, this research extensively investigated a large spectrum of social risk factors for achievement goals and science motivation with a wide sample of individuals as students and specified essential correlates. Following studies had better include more components for achievement goals and investigate its effects on adolescents' science motivation, alongside intervention strategies.

\section{REFERENCES}

[1] Akın, A. (2006). 2X2 Achievement Goal Orientations Scale. Sakarya University Journal of Educational Faculty, 12, 1-13.

[2] Ames, C. (1992). Classrooms: Goals, structures, and student motivation. Educationai Psyctjoiogy, 84, 261-271.

[3] Andrei, C., Izabela, V.P., \& Valentina, Z. (2014). Comparative study between study tracks: Math and sciences or humanities, regarding academic motivation and learning strategies in the 9th Grade Students. Procedia - Social and Behavioral Sciences, 128 (22), 432-437.

[4] Archer, J. (1994). Achievement goals as a measure of motivation in university students. Contemporary Educational Psychology, 19, 430-446.

[5] Arslan,S. \& Akın,A. (2015). 2x2 Başarı yönelimleri ölçeği (Revize Formu): Geçerlik ve güvenirlik çalışması. Sakarya University Journal Of Education, 5 (1),7-15.

[6] Arslan,S., Yılmaz,B., Akcaalan,M., Yılan,A. \& Cavdar,R. (2015). Evaluating The Psychometric Properties of Turkish Version Of The Science Motivation Questionnaire. INTE 2015, International Conference on New Horizons in Education, 10-12 June, Barcelona, Spain.

[7] Bandura, A. (1997). Self-efficacy: The exercise of control. New York: W.H. Freeman.

[8] Bryan, R.R., Glynn, S.M., Kittleson, J.M. (2011). Motivation, achievement, and advanced placement intent of high school students learning science. Science Education, 95 (6), 10491065 . 
[9] Bryman, A. (2004). Social research methods (2nd edition). Oxford: Oxford University Press.

[10] Cain, K. M., \& Dweck, C. S. (1995). The relation between motivational patterns and achievement cognitions through the elementary school years. Merrill-Palmer Quarterly, 41(1), 25-52.

[11] Church, M.A., Elliot, A.J., \& Gable, S.L. (2001). Perceptions of classroom environment, achievement goals, and achievement outcomes. Journal of Educational Psychology, 93, 43-54.

[12] Dowson, M., \& McInerney, D. (2001). Psychological parameters of students' social and work avoidance goals: A qualitative investigation. Journal of Educational Psychology, 93(1), 35-42.

[13] Dweck, C. S. (1986). Motivational processes affecting learning. American Psychologist, 41(10), 1040-1048. doi:10.1037/0003-066X.41.10.1040

[14] Dweck, C. S., \& Elliot, E. S. (1983). Achievement motivation. In P. Mussen \& E. M. Heatherington, (Eds.), Handbook of child psychology (Vol. 4, pp. 643-693), New York: Wiley.

[15] Elliot, A.J. \& McGregor H.A. (2001). A 2 X 2 achievement goal framework. J Pers Soc Psychol. 80(3):501-519.

[16] Elliot, A. J., Maier, M. A., Binser, M. J., Friedman, R., \& Pekrun, R. (2009). The effect of redon avoidance behavior in achievement contexts. Personality and Social Psychology Bulletin, 35, 365-375.

[17] Elliot, E. S., \& Dweck, C. S. (1988). Goals: An approach to motivation and achievement. Journal of Personality and Social Psychology, 54(1), 5-12. doi:10.1037/0022-3514.54.1.5.

[18] Elliot, E.S., McGregor, H.A., Gable, S.L. (1999). Achievement goals, study strategies, and exam performance: A mediational analysis. Journal of Educational Psychology, 91, 549-563.

[19] Garcia, T., \& Pintrich, P.R. (1992). Critical thinking and its relationship to motivation, learning strategies, and classroom experience. Paper presented at the Annual Meeting of the American Psychological Association, Washington, DC, August.

[20] Glynn, S. M., Brickman, P., Armstrong, N., \& Taasoobshirazi, G. (2011). Science motivation questionnaire II: Validation with science majors and nonscience majors. Journal of research in science teaching, 48(10), 1159-1176.

[21] Kaplan, A., \& Maehr, M. L. (1999). Achievement goals and student well-being. Contemporary educational psychology, 24(4), 330-358.

[22] Kuhl, J. (2000). A functional-design approach to motivation and self-regulation. The dynamics of personality systems interactions. In In M. Boekaerts, P. R. Pintrich, \& M. Zeidner (Eds.), Handbook of self-regulation (pp. 111-150). San Diego, CA: Academic.

[23] Kuyper, H., van der Werf, M.P.C., \& Lubbers, M.J. (2000). Motivation, meta-cognition and Evaluation, 6(3), 181-201.

[24] Lee, O. (1989). Motivation to learning science in middle school classrooms. University Microfilms International. Unpublished doctoral dissertation, Michigan State University, East Lansing.
[25] Lee, O., \& Brophy, J. (1996). Motivational patterns observed in sixth-grade science classrooms. Journal of Research in Science Teaching, 33(3), 585-610.

[26] Maehr, M. L. (1989). Thoughts about motivation. In C. Ames \& R. Ames (Eds.), Research on motivation in education (Vol. 3). New York: Academic Press.

[27] McCombs, B. L. (1996). Alternative perspectives for motivation. In L. Baker, P. Afflerbach, \& D. Reinking (Eds.), Developing engaged readers in school and home communities (pp. 67-87). Mahwah, NJ: Erlbaum.

[28] Meece, J. L., \& Jones, M. G. (1996). Gender differences in motivation and strategy use in science: Are girls rote learners? Journal of Research in Science Teaching, 33(4), 393-406.

[29] Midgley, C., Arunkumar, R., \& Urdan, T. (1996). If I don't do well tomorrow, there's a reason: Predictors of adolescents' use of academic self-handicapping strategies. Journal of Educational Psychology, 88, 423-434.

[30] Midgley, C., \& Urdan, T. (2001). Academic self-handicapping and achievement goals: A further examination. Contemporary educational psychology, 26(1), $61-75$.

[31] Napier, J. D., \& Riley, J. P. (1985). Relationship between affective determinants and achievement in science for seventeen-year-olds. Journal of Research in Science Teaching, 22, 365-383.

[32] Nicholls, J. G. (1989). The competitive ethos and democratic education. Cambridge, MA: Harvard University Press.

[33] Nolen, S. B., \& Haladyna, T. M. (1990). Motivation and studying in high school science. Journal of Research in Science Teaching, 27, 115-126.

[34] Omar, S., Jain, J., Noordin, F. (2013). Motivation in Learning and Happiness among the Low Science Achievers of a Polytechnic Institution: An Exploratory Study. Procedia Social and Behavioral Sciences, 90, 702-711.

[35] Pajares, F., Britner, S. L., \& Valiante, G. (2000). Relation between achievement goals and self-beliefs of middle school students in writing and science. Contemporary educational psychology, 25(4), 406-422.

[36] Paris, S. G., \& Turner, J. C. (1994). Situated motivation. In P. R. Pintrich, D. R. Brown, \& C. E. Weinstein (Eds.), Student motivation, cognition, and learning: Essays in honor of Wilbert G.McKeachie (pp. 213-238). Hillsdale, NJ: Erlbaum.

[37] Pintrich, P. R. (2000). An achievement goal theory perspective on issues in motivation terminology, theory, and research. Contemporary Educational Psychology 25, 92-104.

[38] Pintrich, P.R., \& Garcia, T. (1991). Goal orientation and self-regulated learning in the college classroom: a cross-cultural comparison. Student Motivation Plenum Series on Human Exceptionality, pp 149-169.

[39] Pintrich, P.R., Marx, R.W., \& Boyle, R.A. (1993). Beyond cold conceptual change: The role of motivational beliefs and classroom contextual factors in the process of conceptual change. Review of Educational Research, 63(2), 167-199.

[40] Stake, J. E. (2006). The Critical Mediating Role of Social Encouragement for Science Motivation and Confidence among High School Girls and Boys1. Journal of Applied Social Psychology, 36(4), 1017-1045. 
[41] Stipek, D. J. (1996). Motivation and instruction. In D. C. Berliner \& R. C. Calfee (Eds.), Handbook of Educational Psychology (pp. 85-113). New York: Macmillan.

[42] Tapola, A. \& Niemivirta, M. (2008). The role of achievement goal orientations in students' perceptions of and preferences for classroom environment. British Journal of Educational Psychology, 78, 291-312.
[43] Tuan, H.L., Chin, C.C., Shieh, S.H. (2005). The development of a questionnaire to measure students' motivation towards science learning. International Journal of Science Education, 27 (6), 639-654. 